Working Paper No. 567, 2001

The Impact of Foreign Board Membership on Firm Value

by Lars Oxelheim and Trond Randøy

IUI, The Research Institute of Industrial Economics

P.O. Box 5501

SE-114 85 Stockholm

Sweden 


\title{
The Impact of Foreign Board Membership on Firm Value
}

\author{
Lars Oxelheim, Lund University, Sweden and \\ Research Institute of Industrial Economics (IUI), Sweden \\ $\&$ \\ Trond Randøy, Agder University College, Norway and Agder Research Foundation, Norway
}

December 10, 2001

Forthcoming in Journal of Banking and Finance

\begin{abstract}
This study examines the effect of foreign (Anglo-American) board membership on corporate performance measured in terms of firm value (Tobin's Q). On a basis of firms with headquarters in Norway or Sweden the study indicates a significantly higher value for firms that have outsider AngloAmerican board member(s), after a variety of firm-specific and corporate governance related factors have been controlled for. We argue that this superior performance reflects the fact that these companies have successfully broken away from a partly segmented domestic capital market by "importing" an Anglo-American corporate governance system. Such an "import" signals a willingness on the part of the firm to expose itself to improved corporate governance and enhances its reputation in the financial market.

JEL Classification: F36, G30, G32

Keywords: Foreign board membership, corporate governance, board monitoring, cross-listing

* The authors have contributed equally to this study. Corresponding author is Trond Randøy, Agder University College, School of Business and Economics, Serviceboks 422, Bygg H, N-4604 Kristiansand, NORWAY, Phone (47) 38141060, Fax (47) 3814 1061, E-mail: trond.randoy@hia.no
\end{abstract}




\section{The Impact of Foreign Board Membership on Firm Value}

\section{Introduction}

The process of globalization affects the equity value of a firm for a multiplicity of reasons. One important reason is that it removes barriers to trade and capital flows. Another, which is the focus of this paper, is because it reduces firm-level barriers to cross-border information flows and corporate governance. This process of globalizing corporate governance systems has recently been invigorated by the general abolition of capital controls and better access to a global shareholder base (OECD, 1998; Lannoo, 1999; Aguilera and Cuervo-Cazurra, 2000). Historically, systematic differences between countries with regard to law and enforcement have accounted for substantial variations in financial development and performance (La Porta et al., 1997, 1998; La Porta, Lopez-de-Silanes and Shleifer, 1999).

The ongoing process of globalizing equity markets and corporate governance systems offers firms greater financial flexibility, which in turn provides them the opportunity to cut down their cost of capital by reducing cross-border information gaps and agency costs (Karolyi, 1998; Useem, 1998; Stulz, 1999; Bekaert and Harvey, 2000; Randøy, Oxelheim and Stonehill, 2001). The removal of barriers to cross-border investment has given firms the alternative of breaking away from the corporate governance system of the country in which they have their headquarters. Essentially, the firm can opt for one of four corporate governance systems: the Anglo-American system, the German system, the Latin system or the Japanese system (see e.g. Shleifer and Vishny, 1997 and Georgen, 1998).

Corporate governance concerns the legal, institutional, and cultural mechanisms that help 
owners and other stakeholders to exercise control over corporate insiders and management (e.g., Shleifer and Vishny, 1997; John and Senbet, 1999; Peace and Osmond, 1999). The AngloAmerican system is commonly regarded as the most demanding corporate governance system. The "superiority [in market performance] of the Anglo-American model of corporate governance" is widely recognized (see e.g. Economist, 2001: 32). The strict information requirements imposed by the Securities and Exchange Commission (SEC) provide further reasons for regarding the Anglo-American system in general and the US system in particular as a good proxy for a "global" governance model.

When it comes to handling agency-cost and information problems, the reward for switching to the Anglo-American system from a less demanding arrangement appears in the shape of a lower cost of capital and a higher firm value (Stulz, 1999). The potential net gains from complying with the Anglo-American systems need to be appraised after allowing for the substantial costs that compliance itself incurs. These costs arise from such factors as more extensive accounting and reporting (e.g. a second annual report in another language - English), the need for a broader and more qualified investor-relations staff, and more top management time allocated to investors (Howe and Klem, 1987; Useem, 1998; Glaum, 2000).

This paper analyzes the potential for creating value as a result of breaking away from a partly segmented capital market. The generally recognized way of breaking away from a domestic capital market is via international cross-listing (e.g., Howe and Madura, 1990; Sundaram and Louge, 1996; Foerster and Karolyi, 1999; Miller, 1999). Here we suggest an alternative approach, i.e. signaling compliance with the Anglo-American corporate governance system by including representatives of that system on the firm's board. Using the Anglo-American corporate governance system as a proxy for a global system, we emphasize the potential value that can be 
created by having outsider representatives of that system on the board of non-Anglo-American firms.

The empirical analysis in this study is based on companies in Norway and Sweden. The advantage of breaking away from a segmented or partly segmented capital market is likely to be the greatest for (large) companies based in small capital markets (Stulz, 1999). The existence of market segmentation or partial segmentation implies that smaller capital markets are not fully integrated with the global capital market, usually due to cross-border information asymmetries and/or institutional and legal barriers. Whereas the institutional and legal barriers to foreign investment have become less of an issue in Scandinavia, cross-border information asymmetries are still very much in the picture (Dahlquist and Robertsson, 2001; Oxelheim, 2001). Companies from partly segmented capital markets such as Norway and Sweden have access to a limited domestic shareholder base that makes domestic equity expensive or even unavailable (Oxelheim et al. 1998). Consequently we expect an evaluation of companies in Norway and Sweden to show a positive effect from breaking out of any of the partially segmented capital markets in these two countries. Norway and Sweden demonstrate a set of information and institutional barriers such that the result should be applicable to other countries of a similar kind.

The paper is organized as follows. In Section 2 we discuss the attributes and implications of a global/Anglo-American corporate governance regime and describe corporate routes to compliance with that regime. The proposed relationship between Anglo-American board membership and firm value is presented in Section 3. Section 4 provides some stylized facts about corporate governance in Norway and Sweden. Section 5 describes the methodology and data. The empirical results and their interpretation are presented in Section 6. In Section 7 we summarize the key findings and suggest some managerial implications. 


\section{Routes to Compliance with a Global Corporate Governance Regime}

We suggest that two major approaches are available to non-Anglo-American companies in breaking away from a domestic corporate governance model in favor of the more demanding Anglo-American corporate governance system: (i) Anglo-American foreign exchange listing, and (ii) Anglo-American foreign board membership. The key ingredients of both alternatives are the bridging of a cross-border information gap, and an improvement in corporate governance. In both cases value can be created through access to new investors. New and/or improved access to a foreign investor clientele should entail a higher share price, and thus a lower cost of capital (Oxelheim et al. 1998; Bekaert and Harvey, 2000).

Foreign exchange listing is the most widely recognized way of breaking out of a segmented home market with the view to reducing the cost of capital. ${ }^{1}$ To our knowledge there are no studies with this aim in mind that address the alternative of foreign board membership. A foreign exchange listing signals a firm's commitment to the higher disclosure standards prevailing in the market in which it lists. Eventually the signaling will boost foreign investors' recognition of the firm. The potential value-enhancing effect of listing is based on a greater ability to attract new investors. For example, Howe and Madura (1990), Sundaram and Louge (1996), Foerster and Karolyi (1999), and Miller (1999) analyze the effects of cross-listing and report positive cumulative abnornal returns, albeit varying in magnitude. Foreign ownership thus becomes a means for achieving a lower cost of capital. The firm can also opt to comply more forcefully by simultaneously placing an equity issue on the relevant market. Modén and Oxelheim (1997) and Karolyi (1998), analyze the abnormal returns following the announcement of a foreign equity issue, and report higher positive abnormal returns than in the case of a listing only. 
The globalization of ownership creates an opportunity for foreign shareholders to buy large stakes in the firm. However, the investors must have confidence that the capital they provide will be properly monitored. For small shareholders the cost of getting involved may be prohibitive. But larger shareholders can afford active monitoring, for instance through foreign board membership (Shleifer and Vishny, 1986). Board representatives for large foreign shareholders are presumably "outsiders" who will not use their influence as board members to obtain benefits that do not accrue to other shareholders (see, e.g. Stulz, 1999). As they are more likely to perform the arm's-length monitoring, their entry as owners should increase the value of the firm.

Compliance with the stricter information and monitoring requirements of a more demanding corporate governance system can substantially increase a firm's costs. This also discourages managers from extracting private benefits, and it therefore strengthens the firm's commitment to protecting the interests of minority shareholders (Reese and Weisback, 2001). Foreign listing - or the undertaking of foreign equity issues - is a costly affair for the firm, both in terms of outright expenses and in terms of top management involvement (Oxelheim et. al. 1998; Blass and Yafeh, 2001).

Many small or medium-sized firms might consider such an alternative too costly. For these firms, however, there is a way of achieving a global cost of capital at a lower outright cost. In exercising this option a firm signals its willingness to improve the monitoring opportunities by including foreign outsider members on the board. This alternative of "importing" a more demanding corporate governance system by having one or more representatives of that system as board members signals a higher commitment to corporate monitoring and transparency. We suggest that the presence of at least one foreign outsider member representing a more demanding 
system, i.e. the Anglo-American system, will result in more active boards that are more independent of management. We argue that Anglo-American board membership strengthens investor confidence, and this signal will eventually lead to an increase in firm value. The underlying assumption is that board members associated with the corporate governance system of the country of their citizenship also bring with them the specific features of that system.

Most past corporate governance studies have presumed implicitly that a company is embedded in the corporate governance model of its home country (e.g. La Porta, 1998, La Porta, Lopez-de-Silanes and Vishny, 1999), unless the firm is a subsidiary of a foreign company. However, an examination of the impact of having an outsider foreign board member reveals three different mandate situations. One alternative is that the board member has a mandate to represent an owner with a major commercial or long-lasting interest in the firm such as a foreign direct investment (FDI) or a subsidiary. A second alternative is that the board member represents a foreign owner with a big portfolio stake in the firm. Finally, the board member may be an independent outsider chosen by the company specifically to signal its willingness to comply with another corporate governance system. The choice is assumed here to be independent of ownership structure. By having at least one foreign board member in this third category and representing the Anglo-American system, the firm is signaling its willingness to be monitored by the rules of a more demanding corporate governance system.

The strongest consistent signal of commitment is assumed to emerge from a combination of a cross-listing on the Anglo-American markets and the inclusion of at least one independently chosen outsider foreign board member representing the Anglo-American corporate governance system. Both these features indicate an improvement in monitoring and an increase in transparency, which we expect to be valued by investors. Hence, the undertaking of an 
international cross-listing should not, on its own, be regarded as a completed mission.

\section{Effects of Anglo-American Board Membership: The Hypotheses}

Past research suggests that a firm's value depends on the quality of the monitoring and decision-making undertaken by its board of directors (Shleifer and Vishny, 1997). A recent survey of investors' opinions around the world reports consistent findings: global investors are willing to pay a significant premium (e.g. $18 \%$ for Swedish firms) for well-governed corporations (McKinsey \& Company, 2000).

In this paper we focus on the alternative of "importing" the Anglo-American corporate governance system by including outsider foreign board members. This signal can have both an immediate and a long-term effect. The immediate effect, which lends itself to the study of the announcement-day effect by applying an event-study methodology, is not addressed here due to problems in identifying appropriate announcement days and in dealing with contaminated information releases. The first of these difficulties stemmed from the fact that of 225 sample firms only two introduced Anglo-American board members during 1996-1998, the period under investigation (no companies dropped any such member). Furthermore, almost half the 29 companies in our sample that had at least one outsider Anglo-American board member in 1998 and that existed in 1990 had introduced foreign board membership prior to 1990.

To identify the long-term effect of the inclusion of Anglo-American board members we have to control for the effects of any other measures aimed at bridging the information and monitoring gaps between the domestic and the Anglo-American corporate governance model. As already noted, the immediate effects of such activities undertaken by Nordic firms have been found to be substantial. In a study of Swedish firms that undertook foreign listings and equity 
issues simultaneously (period 1982 to 1993), Modén and Oxelheim (1997) reported a cumulative abnormal return of $11 \%$ within five days of the announcement day. But there may be long-term effects arising from this action as well. An attempt is needed to distinguish the long-term effects of foreign listing from the effects arising from the "import" of a foreign corporate governance model.

Corporate governance research recognizes the essential role performed by the board of directors in sustaining an effective organization (OECD, 1999; Jensen, 1993). US-based research is inconclusive regarding the effect of outside board members. Some studies suggest that outside directors can enhance firm performance (e.g., Rosenstein and Wyatt, 1990), while others come to the opposite conclusion (e.g., Agrawal and Knoeber, 1996). We add a special angle to this research by examining the case of outside board members representing a foreign corporate governance system, and we claim that in several ways Anglo-American outside board members have a particularly important role with respect to monitoring in companies in small or emerging economies.

There is a limited pool of board candidates in a small country, and a conflict of interest can easily arise in connection with interlocking board membership. We argue that, by increasing the independence of the board, the inclusion of outsider Anglo-American board members should reduce managerial entrenchment. For example, the Oslo Stock Exchange had 217 companies listed at the end of 1997, with a median of six board members per firm. With most outside directors sitting on several boards, many companies may have been experiencing or expecting conflicts of interest among their board members. This makes it more difficult to achieve a wellfunctioning domestic labor market for board members. In light of the above argument we suggest that the inclusion of foreign board members signals that the power of the "old-boy" network is 
being eroded, which in turn will manifest itself in a growing inclination on the part of the board to emphasize truth and frankness in serving their shareholders, rather than giving priority to politeness and courtesy among board members (see Jensen, 1993, for an interpretation of such boardroom behavior).

We suggest that the inclusion of a foreign board member is a "step" forward in a firm's globalization process, and the inclusion of an outsider Anglo-American member means crossing a first hurdle, namely using English as the official language at board meetings. Further, the new member will promote the exchange of information in at least two ways. One is by helping to disseminate information to their international network. Since a number of Scandinavian firms are the object of substantial foreign investment, the additional influence of an outsider AngloAmerican board member could persuade such a company to act more as though they were located in the country of their international investors.

Secondly, we argue that the presence of outsider Anglo-American board members signals a commitment to shareholder rights, something which appeals to investors. It may also signal that the firm is less resistant to possible take-overs and less exposed to managerial entrenchment. We thus claim that an outsider Anglo-American board member brings the interests of shareholders and managers closer together.

\section{Hypothesis 1: There is a positive relation between outsider Anglo-American board membership and firm value.}

We suggest that the relative impact of Anglo-American board membership varies under different corporate governance conditions (i.e. an out-of-equilibrium position in the terminology 
of Demsetz and Lehn, 1985). We expect that due to managerial inertia and self-reinforcing patterns of organizational learning (e.g., Cohen and Levinthal, 1990; Spender 1996), older firms will benefit more from the strict monitoring provided by Anglo-American board membership. Past research indicates that younger founder-controlled firms provide a unique form of corporate governance monitoring (e.g., Jayaraman, Khorana, Nelling, and Covin, 2000; Mishra, Randøy and Jenssen, 2001). We therefore distinguish between younger and older firms and suggest:

\section{Hypothesis 2: Outsider Anglo-American board membership has a greater impact on firm value in older firms than in younger ones.}

A global shareholder base is especially beneficial to large firms based in small countries, since "the risks of equity are shared among more investors with different portfolio exposures and hence a different "appetite" for bearing certain risks" (Stulz, 1999: 24). We suggest that when a single company represents a large share of the total market capitalization of a national equity market, then that firm's need to build confidence in the global investor community is particularly important. Hence, we expect to see outsider international board membership having a greater effect on valuation among firms with a high level of market capitalization.

A firm aspiring to be global needs to spend considerable resources on attracting the attention of the global investment community. This effort should be a top priority for the CEO (Useem, 1998). The cost structure of this investor-relations activity is largely fixed, and is not related to the market capitalization of the firm. It thus represents a barrier for smaller firms. We expect that firm size, measured in terms of market capitalization, is related to the impact of Anglo-American board membership on firm valuation. 


\section{Hypothesis 3: Anglo-American board membership has a more powerful impact on firm value in firms with a high level of market capitalization than in firms with a lower level.}

\section{Corporate Governance in Scandinavia ${ }^{2}$ : Some Stylized Facts}

The corporate governance system in Norway and Sweden can be seen as a modified version of the German system, with a strong focus on the alignment of interests between managers and industrial (corporate) owners (Huse and Eide, 1996). In a review of national culture and corporate governance, Peace and Osmond (1999) identify similarities between the Scandinavian "civil law" corporate governance system and the system in countries such as the Netherlands and Israel. This is also reflected in the legal requirement regarding employee representation on company boards in Norway (governing boards and supervisory boards) and in Sweden (governing boards). However, all votes in both boards are by simple majority (only Norway has two-tiered boards), such that shareholders still hold the ultimate power. ${ }^{3}$ Furthermore, La Porta et al. (1998) argue that investor protection in Norway and Sweden, as one important aspect of corporate governance, is equal or almost equal to that in "common law" countries such as Ireland or Australia.

At the end of 1998 foreign investors held about $31 \%$ of the total market capitalization of the Oslo Stock Exchange, and 33\% of the Stockholm Stock Exchange. This high proportion of foreign ownership is not new to the two exchanges. It developed gradually beginning in the early 1980s when the restrictions on foreign ownership of Norwegian and Swedish firms were eased. After the beginning of 1995 the use of restricted shares (for domestic owners only) was banned in 
accordance with the European Economic Area (EEA) treaty (Oxelheim et al. 1998). Since the mid-1990s about one-third of the market capitalization on both exchanges has been owned by foreign investors (mainly Anglo-Americans).

\section{Methodology and Data}

\subsection{Data}

The data is based on a random sample of 253 traded companies with their headquarters in Norway or Sweden, of which 132 are based in Norway and 121 in Sweden. Companies belonging to all industries except finance, banking, and insurance, are included. Nine companies were later excluded because they employed unusual reporting periods, eleven were excluded because they had been listed for less than three years, and eight companies were omitted because information was missing or because their stock was infrequently traded. This left us with data from 225 Norwegian and Swedish firms. The data set contains 650 firm-year observations in 1996, 1997, and 1998, of which 354 refer to Norway and 296 to Sweden. The sample firms cover over half of all the exchange-traded firms in Norway and about one-third in Sweden during the sample period.

The financial variables were collected from annual reports. Information about some of the corporate governance variables was also publicly available (e.g., Sundqvist, 1999). Data such as the nationality of board members and their mandates were not available from secondary sources. Telephone interviews, with fax follow-ups, were used to identify the nationality of board members and to verify control variables such as the age of the firm and its foreign industrial ownership. Reliable information more closely revealing the mandates of the foreign board members was not available, however, since many foreign board members had joined several decades ago and no historical documentation of their recruitment remained. 


\subsection{Model specification}

Drawing on previous research on corporate governance, the model for testing the hypotheses presented in the preceding section was developed with a variety of independent variables to minimize specification bias. We use cross-sectional ordinary least-square (OLS) regression and two-stage least-square (2SLS) regression to test the presented model. In our model we control for international corporate governance variables (foreign ownership, foreign listing/trading, and foreign subsidiary), general corporate governance variables (board size, board independence and blockholder ownership), and general control variables that have been identified in past studies: firm size (Dalton et al., 1999), industry (Baysinger and Butler, 1985), board independence (e.g., Hermalin and Weisbach, 1991), board size (e.g., Yermack, 1996), and blockholder ownership (e.g., Shleifer and Vishny, 1986).

Past research indicates that the composition of the board may be endogenously determined (e.g., Hermalin and Weisback, 2000). For example, a higher firm value could be a result of the influence and decisions of past board members (including outside Anglo-American members), but could also be a factor influencing potential Anglo-American board members' interest in serving on Scandinavian boards. As recommended by Bhagat and Black (2000), we use a twostage least-square (2SLS) model to address the possible problem of endogeneity. In the 2SLS model we use foreign listing as an instrument variable to substitute for outsider Anglo-American board membership, as foreign listing is highly correlated (0.367) with Anglo-American board membership but exhibits a fairly low correlation (0.097) with firm value. The OLS and 2SLS estimated models of the relation between outsider Anglo-American board membership and firm value (Q-ratio), and the control variables, are as follows: 
OLS regression model (1):

Firm value (Q-Ratio) $=\alpha_{1}+\beta_{1} *$ Anglo-American Board Membership $+\beta_{2} *$ Foreign Ownership + $\beta_{3} *$ Foreign Listing $+\beta_{4} *$ Foreign Subsidiary $+\beta_{5} *$ Board Size $+\beta_{6} *$ Board Independence $+\beta_{7} *$ Blockholder Ownership $+\beta_{8} *$ Firm Size $+\beta_{9} *$ Firm Age + $\beta_{10} *$ Nationality $+\beta_{\mathrm{i}} *$ Industry Dummies

Instrument variables: First step of 2SLS model (2)

Anglo-American Board Membership $=\alpha_{\mathrm{a}}+\beta_{\mathrm{a}}$ *Firm value $+\beta_{\mathrm{b}}$ *Foreign Ownership $+\beta_{\mathrm{c}}$ *Foreign Listing $+\beta_{\mathrm{d}} *$ Foreign Subsidiary $+\beta_{\mathrm{e}} *$ Board Size $+\beta_{\mathrm{f}} *$ Board Independence + $\beta_{\mathrm{g}} *$ Blockholder Ownership $+\beta_{\mathrm{h}} *$ Firm Size $+\beta_{\mathrm{k}} *$ Firm Age $+\beta_{1} *$ Nationality + $\beta_{\mathrm{x}}{ }^{*}$ Industry Dummies

Explanatory variables: Second step of 2SLS model (3)

Firm value (Q-Ratio) $=\alpha_{\mathrm{aa}}+\beta_{\mathrm{ab}} *$ Anglo-American Board Membership $+\beta_{\mathrm{ac}} *$ Foreign Ownership $+\beta_{\mathrm{ad}} *$ Foreign Subsidiary $+\beta_{\mathrm{ae}} *$ Board Size $+\beta_{\mathrm{af}} *$ Board Independence $\beta_{\mathrm{ag}} *$ Blockholder Ownership $+\beta_{\mathrm{ah}} *$ Firm Size $+\beta_{\mathrm{ai}} *$ Firm Age $+\beta_{\mathrm{aj}} *$ Nationality + $\beta_{\mathrm{ax}} *$ Industry Dummies

\subsection{Definition of variables}

The dependent variable firm value is measured by the year-end q-value in 1996, 1997 and 1998. The q-value is defined as the ratio of the market value of the firm to the book value of total assets. To reduce heteroskedasticity, we use the natural logarithm of the q-value as the dependent variable. The market value of the firm is measured by the sum of the market value of equity and the book value of total liabilities. The applied q-value measure is an approximation of Tobin's Q (Perfect and Wiles, 1994; Chung and Pruitt, 1994), a firm value measure that is widely used (see e.g. Morck et al., 1988, McConnell and Servaes 1990, Yermack 1996, McConaughy et al. 1998, and La Porta, Lopez-de-Silanes and Vishny, 1999). In this approximation of Tobin's Q, the replacement cost of total assets and the market value of total debt are approximated by their book values.

The three kinds of independent variable mentioned previously are all measured on a yearby-year basis. The explanatory variable outsider Anglo-American board membership in the group 
of international corporate governance variables is measured as 1 , if one (or more than one) "outsider" board member is a citizen of either the US, Canada or the UK; 0, otherwise. A director is considered an "insider" director when he or she is or has been directly or indirectly employed by the firm. We choose not to use the share of outsider Anglo-American board members, since the signaling effect of adherence to the Anglo-American corporate governance system would be achieved by the inclusion of even one Anglo-American board member.

In the absence of data on the specific mandate of the foreign board member, foreign ownership is used as a proxy for foreign portfolio ownership. It is measured as the share (percentage) of equity held by foreign citizens or foreign institutions (all nationalities) in relation to the total equity (all share classes) of the firm. We have not been able to break this down by home country, which means that we cannot identify the proportion of a firm owned by AngloAmerican investors. However, Dahlquist and Robertsson (2001) report that in 1997 as much as $67.2 \%$ of all Swedish shares held by foreigners were held by US or UK investors/institutions, and at the end of 1998 a similar figure in Norway was 63.4\% (Oslo Stock Exchange, 1999).

We use a dummy variable for firms that are foreign subsidiaries. This is a proxy variable to separate the effects of outsider Anglo-American board members representing the owners of such companies (the FDI-mandate effect). Companies with a single foreign industrial owner holding $20 \%$ or more of the firm's equity (any share class) are classified here as foreign subsidiaries. Some studies indicate the need for a higher share of the ownership and unambiguous control as a prerequisite for higher returns (see e.g. Chhibber and Majumdar, 1999, in a study of Indian firms). However, given the fact that minority ownership rights are relatively strong in Scandinavia (La Porta et al., 2000), we expect such effects to appear even at the $20 \%$ level.

A dummy (value 1 for foreign listing, 0, otherwise) is used to identify firms that are listed 
or traded on one or more Anglo-American foreign exchanges, such as NYSE, NASDAQ, USA OTC (ADRs), London Stock Exchange, or SEAQ International

We use three general corporate governance variables. Board size is the number of directors on the board at the end of each sample year. Board independence is the end of year percentage of independent outsider directors. We have excluded employee or union representatives from the measure of board independence, since employee representation is mandatory in larger companies in both Norway and Sweden. Blockholder ownership is the percentage of all shares that are owned by the three largest shareholders.

Among the general control vaiables, firm size is measured by taking the natural logarithm of total revenues for each year, as the size alone is not normally distributed. Firm age is measured by the logarithm of the number of years between the observation year and the firm's founding year. We control for industry effects by using six industry groups.

The legal, cultural and political resemblances between Sweden and Norway suggest that corporate governance is also likely to be rather similar. However, there are some differences. Norwegian companies, for instance, have, as was previously mentioned, a two-tier board, which is not the case in Sweden. To check the magnitude of these differences we use a nationality dummy. Separate tests for each country are also reported (Table 6).

\section{Empirical Findings}

\subsection{Sample characteristics and univariate tests}

Table 1 gives the mean values of the variables used in the study and the F-statistics (twotailed) that test the mean differences between firms with and without Anglo-American board members. $13 \%$ of the firms had one or more Anglo-American board members (84 firm-year 
observations), a figure that rose from $12 \%$ in 1996 to $13 \%$ in 1998. The share of Anglo-American board members was $10 \%$ in Norway and $16 \%$ in Sweden. The higher ratio of Anglo-American board membership in Sweden reflects the greater average size of Swedish firms on the Stockholm Stock Exchange, and the fact that Anglo-American board representation increases with firm size (0.254 correlation). Among the world's 81 largest multinational firms, Gillies and Dickinson (1999) find that 36\% had at least one foreign board member in 1993.

The average (unweighted) foreign ownership in the sample is $19 \%$. After adjustment for market capitalization, however, the average foreign ownership in our sample is $34 \%$ in Norway and $38 \%$ in Sweden. In this respect the sample is representative, since the corresponding figure among all exchange-traded firms in Norway is 31\% and in Sweden 33\% (Oslo Stock Exchange, 1999; Dahlquist and Robertsson, 2001). ${ }^{4}$

\section{Insert Table 1 about here}

In our univariate analysis in Table 1 we find that firm value, as measured by the $\ln \mathrm{q}-$ value, is significantly higher for firms with outsider Anglo-American board membership, which is consistent with hypothesis 1 . When all industries are considered together, the average ln q-value for firms with outsider Anglo-American board membership is 0.61 , and the average ln q-value for firms without outsider Anglo-American board membership is 0.36 . The difference between the two groups is significant at a $0.1 \%$ level. The q-value for companies with outsider AngloAmerican board membership is 2.78 and for companies without such board membership 1.59.

Table 1 shows that firms with outsider Anglo-American board members differ in many respects relative to firms without such board membership. Firms with Anglo-American board 
members have a significantly higher level of foreign ownership (39\% versus 15\%), a greater tendency towards foreign listing/trading (44\% versus $8 \%$ ), and a greater likelihood of being a foreign subsidiary (23\% versus $4 \%$ ). They are also significantly larger and older, as well as having more people on their boards.

On the basis of the industry classifications used by the Oslo and Stockholm Stock Exchanges, we group our sample firms into six industry groups. The relatively small number of firms that have outsider Anglo-American board members prevent us from breaking these firms down into even smaller and more homogenous industry groups. The six groups are (1) property and retail, (2) manufacturing, (3) information technology and telecom, (4) media and publishing, (5) transportation and shipping, and (6) other industries. The bivariate analysis of the industry grouping is shown in Table 1. This shows that firms with outsider Anglo-American board members exhibit a significantly higher value (1\%-level) than firms without such board membership in all industries except retail \& property and the shipping \& transportation. The difference is strongest in information technology \& telecom and media \& publishing. We use dummies for the first five industry groups and "other industries" as our benchmark case in the regressions (shown below in Tables 3 and 4). We also run separate regressions for each industry group (Table 5).

The four variables related to international corporate governance are significantly correlated with each other (Table 2). However, the correlations between the international corporate governance variables are still low enough not to cause multicollinearity problems. The highest correlation (0.0382) is between foreign ownership and outsider Anglo-American board membership. These not too low and not too high correlations lend support to the basic choice of design for this study, as we have argued that the four international governance variables need to 
be addressed as separate aspects of a firms' globalization of capital within a multivariate framework.

\section{Insert Table 2 about here}

The correlations in Table 2 indicate that both routes to complying with the global corporate governance model (cross-listing on Anglo-American markets and outsider AngloAmerican board membership) are significantly and positively correlated with the q-value. As predicted in Hypothesis 1, firm value has a positive and significant correlation (1\%-level) of 0.177 with Anglo-American board membership.

\section{Insert Table 3 about here}

\subsection{Multivariate tests}

The regression estimates of our model in Equation 1 appear in Tables 3 and 4. To enhance the reliability of our tests, we performed separate tests for each sample-year (Table 3) and a pooled regression for all three sample-years (Table 4). The tests in Table 3 show that the value effect of outsider Anglo-American board membership is significantly positive for each sample year (albeit only at a 10\%-level for 1996). As shown in Table 4, the pooled regression model has an acceptable explanatory power for a cross-sectional study (adjusted r-squared $=37.1 \%$ ) and all the tested models are highly significant $(\mathrm{p}<0.001)$.

\section{Insert table 4 about here}


In Table 4 we first conduct a logistic regression to explore further various factors that relate to outsider Anglo-American board membership. Our results indicate that foreign board membership is significantly related to firm value (positive), foreign ownership (positive), foreign listing (positive), foreign subsidiary (positive), board independence (negative), and blockholder ownership (positive). To address possible endogeneity in the model design, we then performed two-stage least-square tests based on Equations 2 and 3. The 2SLS model produces results consistent with the OLS model as regards the effect of outside Anglo-American board membership. This suggests that endogeneity effects are not a major problem. Furthermore, the 2SLS and the OLS results are rather similar in connection with a breakdown by industry (Table 5), by firm size, firm age, and nationality (Table 7), and so we display the OLS results only in Tables 5 and 6. In light of the analyses in Tables 1-4 we suggest that the inclusion of at least one outside board member representing the Anglo-American corporate governance system on company boards in Norway and Sweden does have a positive valuation effect (Hypothesis 1).

Table 5 shows that the association between outsider Anglo-American board membership and firm value is highly contingent on industry affiliation. We identify outsider Anglo-American membership as having the strongest significant effect among manufacturing, information technology \& telecom firms, and to some extent also among media \& publishing firms. A possible explanation for the observed effect of this industry affiliation is the relative importance of cost of capital in these "high tech" industries, and the fact that they lack the collateral needed for debt financing. In contrast, shipping, transportation, property \& retailing can rely on traditional debt financing. By lowering the cost of capital and increasing its availability the hightech firms are able to undertake more $R \& D$, while collateral-based debt financing is still available 
to the low-tech firms at the same low cost of capital. This is also consistent with the argument presented by Carlin and Mayer (1999), namely that bank-based financial systems (the Scandinavian case) are less capable than market systems (i.e., the Anglo-American) of providing financing for new technology.

\section{Insert Table 5 about here}

Foreign board membership is an essential part of a corporate governance structure that determines the firm's value and the allocation of resources among various stakeholders. Our results may be open to the criticism raised by Demsetz (1983) and Cho (1998) that ownership structure is an outcome of a selection process that produces a unique firm-specific equilibrium. The same theoretical argument could also apply to board effectiveness, including the kind that might be generated by outsider Anglo-American board membership. Essentially one could ask: are companies successful because they have outsider Anglo-American board members, or could it be that these firms attract such board members because they are successful? In other words, it is difficult to be certain about the causal direction of the reported associations. A related issue concerns the possible endogenous nature of corporate governance variables tested here (including foreign board membership), a point raised by Demsetz and Lehn (1985) and addressed earlier in this paper.

We have addressed these weaknesses here by grounding the hypotheses solidly in agency and financial market theory, and by controlling for a number of factors that could affect outsider Anglo-American board membership (such as size, firm age, ownership structure). Specifically, we control for the effect of industry and of various corporate governance conditions. Further, we ran 
the model over a three-year period in which we saw only minor changes in outsider AngloAmerican board membership (Table 3), which suggests that outsider Anglo-American board membership is quite stable and does not adjust rapidly to changes in a firm's profitability or market value. This suggests in turn that for the duration of our three-year study period outsider Anglo-American board membership is an exogenous variable.

In line with Hypothesis 2, we find the value of Anglo-American board membership to be higher for older firms than for younger ones. However, the difference is only a matter of degree of significance: the value-enhancing effect on younger firms is significant, but not as significant as in the case of older firms (see Table 6). This is in line with our argument that the inclusion of Anglo-American board members is likely to be most beneficial to older firms.

\section{Insert Table 6 about here}

As indicated by Hypothesis 3, the regression results suggest that Anglo-American board membership adds more value to firms with a high level of market capitalization (over SEK one billion) than to those with a lower level. However, we find a positive value for small firms as well, albeit at the 5\%-level of significance only. This suggests that the payoff from AngloAmerican board membership is not as closely related to certain fixed cost thresholds as one might imagine. This suggests in turn that the organizational costs of Anglo-American board membership (e.g., internal reporting in English) may be offset even in the case of smaller firms.

Finally, the methodological issue of a possible reversed causality - i.e., that a high q-ratio could actually cause a higher level of foreign board membership - deserves further attention. First, as was shown in Table 4, the 2SLS regression indicates no such reverse causality in the 
relationship between the q-ratio and outsider Anglo-American board membership. Secondly, the corporate governance literature suggests that the boards of well-governed firms penalize executives of badly performing firms (e.g., Kaplan, 1995). The t-tests in Table 7 indicate that the CEO turnover in our Norwegian and Swedish firms with outside Anglo-American board membership is more sensitive to performance, i.e. firms with outside Anglo-American board membership are apparently more likely to fire a CEO after a period of poor performance. This is a further indication of the causality that we claim does exist and of the validity of the basic assumption we have made for the value creating process, i.e. that outsider Anglo-American board members provide firms with superior corporate governance.

\section{Insert Table 7 about here}

\section{Concluding Remarks and Policy Recommendations}

Previous studies suggest that a foreign stock listing on an Anglo-American exchange particularly when it is combined with a foreign issue - can increase the value of the firm and thus reduce its corporate cost of capital. This study finds that firms in countries whose financial markets are only partially integrated can create significant value by "importing" the AngloAmerican governance by including one or more Anglo-American "outsider" members on their boards. This provides firms in smaller countries with an alternative way of introducing AngloAmerican corporate governance, and one that should appeal especially to small or medium-sized firms.

This study argues that recruitment of an outsider Anglo-American board member can be seen as an alternative avenue to reduce cost of capital that complements the traditional route of 
seeking foreign listing. We suggest that Anglo-American board membership enhances the international orientation of the firm, and serves as a catalyst for further globalization of a corporation. Having an Anglo-American citizen on the board is a value statement that signals openness to foreign investors and a commitment to corporate transparency, i.e., adherence to the Anglo-American corporate governance model.

We have argued that Anglo-American board membership has a significantly positive impact on both small and large exchange-traded firms. This effect appears to be stronger in the case of firms that are larger (more than SEK 1 billion in market capitalization) and older (more than 30 years old), and in industries such as manufacturing, IT \& telecom, and media \& publishing. We emphasize that although our overall results suggest that the average firm can benefit from Anglo-American board membership, there are certain firm-specific contingencies that may reduce the value arising from the inclusion of outsider Anglo-American board members.

The main recommendation of this paper for corporate policy is that firms based in small or emerging equity markets should consider the potential gains of breaking away from their domestic corporate governance system, either by including one or more Anglo-American board members or by listing on an Anglo-American stock exchange. The long-term value arising from the inclusion of an Anglo-American outsider board member seems to exceed that of a crosslisting on an Anglo-American market. Hence, the inclusion of an outsider Anglo-American board member should be seen not only as a low-budget alternative for firms that regard cross-listing as too big a venture, but also as an important complement for firms where cross-listing already exists. 


\section{Acknowledgements}

This article has been greatly improved by comments offered by Arthur Stonehill, and by participants at seminars at the Oslo Stock Exchange, at UC Santa Barbara, and at Lund University, Sweden. Earlier versions of this paper were presented at the Annual Financial Management Association meeting in Toronto (October 2001), and the Annual Academy of Management meeting in Washington D.C. (August 2001). Generous financial contributions to the research were made by the Agder Maritime Research Foundation, Norway and the Savings Bank Foundation Skåne, Sweden. We gratefully acknowledge the extensive work of data collection undertaken by Johan Boström.

\section{References}

Agrawal, A., Knoeber, C., 1996. Firm performance and mechanisms to control agency problems between managers and shareholders. Journal of Financial and Quantitative Analysis 31, 377-397.

Aguilera, R., Cuervo-Cazurra, A., 2000. Codes of Good Governance Worldwide. University of Illinois at Urbana-Champaign, CIBER working paper 00-105.

Barca, F., Becht, M. (editors), 2001. The Control of Corporate Europe. Oxford University Press, Oxford.

Baysinger, B., Butler, H., 1985. Corporate governance and the board of directors: performance effects of changes in board composition. Journal of Law, Economics, and Organizations 1, 101-124.

Bekaert, G., Harvey, C., 2000. Foreign speculators and emerging equity markets. Journal of Finance 55, 565-613.

Bhagat, S., Black, B., 2000. Board independence and long term firm performance, Colombia Law School, The Center for Law and Economics, Working Paper.

Blass, A., Yafeh, Y., 2001. Vagabond shoes longing to stay: Why foreign firms list in the United States. Journal of Banking and Finance 25, 555-572.

Carlin, W., Mayer, C., 1999. Finance, Investment and Growth. Discussion Paper No. 2223. CEPR, London.

Chhibber, S., Majumdar, K., 1999. Foreign ownership and profitability: property rights, control, and the performance of firms in Indian industry. Journal of Law and Economics 42, 209-238.

Cho, M-H., 1998. Ownership structure, investment, and the corporate value: an empirical analysis. 
Journal of Financial Economics 47: 103-121.

Chung, K., Pruitt, S., 1994. A simple approximation of Tobin's q. Financial Management 23 (3), 70-74.

Cohen, W., Levinthal, D., 1990. Absorptive capacity: A new perspective on learning and innovation. Administrative Science Quarterly 35, 209-225.

Dahlquist, M., Robertsson, G., 2001. Direct foreign ownership, institutional investors, and firm characteristics. Journal of Financial Economics 59, 413-440.

Dalton, D., Daily, C., Johnson, J., Ellstrand, A., 1999. Number of directors and financial performance: A meta-analysis. Academy of Management Journal 42, 674-687.

Danish Ministry of Finance, 1999. Debatopplæg om Aktivt Eierskap, Schultz Erhvervsboghandel: Copenhagen.

Demsetz, H. 1983., The structure of ownership and theory of the firm. Journal of Law and Economics 26 (2), 375-394.

Demsetz, H., Lehn, K., 1985. The structure of corporate ownership: causes and consequences. Journal of Political Economy 93 (6), 1155-1177.

Economist, 2001. Global Equity Markets Survey. May $5^{\text {th }}$.

Glaum, M., 2000. Bridging the GAAP: the Changing Attitude of German Managers towards AngloAmerican Accounting and Accounting Harmonization. Journal of International Financial Management and Accounting 11 (1), 23-47.

Goergen, M., 1998. Corporate Governance and Financial Performance. A Study of German and UK Initial Public Offerings. Edgar Elgar, Cheltenham, UK.

Gillies, J., Dickinson, M., 1999. The governance of transnational firms: some preliminary hypotheses. Corporate Governance - an International Review 7, $237-247$.

Hermalin, B., Weisbach, M., 1991. The effects of board composition and direct incentives on firm performance. Financial Management 20 (4), 101-112.

Hermalin, B., Weisbach, M., 2000. Boards of directors as an endogenously determined institution: A survey of the economic literature, University of Berkeley, Working Paper.

Howe, John and Kathryn Kelm. 1987. The stock price impact of of overseas listings. Financial Management (Autumn): 51-56.

Howe, John, \& Jeff Madura, 1990. The impact of international listing on risk: Implications for capital market integration. Journal of Banking and Finance 14, 1133-1142.

Huse, M., Eide, D., 1996. Stakeholder management and the avoidance of corporate control. Business and Society 35, 211-243.

Eaton, J., Rosen, H., 1983. Agency delayed compensation, and the structure of executive remuneration. Journal of Finance 38, 1489-1505. 
Foerster, S., Karolyi, A., 1999. The Effects of market segmentation and investor recognition on asset prices: Evidence from foreign stocks listing in the U.S. Journal of Finance 54, 981-1013.

Jensen, M., 1993. The modern industrial revolution, exit, and the failure of internal control systems. Journal of Finance 48, 831-881.

John, K., Senbet, L., 1999. Corporate governance and board effectiveness. Journal of Banking and Finance 22, 371-403.

Kaplan, S., 1995. Corporate Governance and Incentives in German Companies: Evidence from Top Executive Turnover and Firm Performance. European Financial Management 1: 23-36

Karolyi, A., 1998. Why do companies list shares abroad? A survey of the evidence and its managerial implications. Financial Markets, Institutions and Instruments 7, (1), 1-60.

Lannoo, K., 1999. A European perspective on corporate governance. Journal of Common Market Studies 37, 269-294.

La Porta, R., Lopez-de-Silanes, F., Shleifer, A., 1999. Corporate ownership around the world. Journal of Finance 54, 471-517.

La Porta, R., Lopez-de-Silanes, F., Shleifer, A., Vishny, R., 1997. Legal determinants of external finance. Journal of Finance 52, 1131-1150.

La Porta, R., Lopez-de-Silanes, F., Shleifer, A., Vishny, R., 1998. Law and finance. Journal of Political Economy 106, 1113-1155.

La Porta, R., Lopez-de-Silanes, F., Shleifer, A., Vishny, R., 2000. Investor Protection and Corporate Valuation. Journal of Financial Economics 58 (1-2), Special Issue on International Corporate Governance, 3-27.

McConaughy, D., Walker, M., Henderson, G., Mishra, C., 1998. Founding family controlled firms: Efficiency and value. Review of Financial Economics 7, 1-19.

McConnell, J., Servaes, H., 1990. Additional evidence on equity ownership and corporate value. Journal of Financial Economics 27, 595-612.

McKinsey \& Company, 2000. Investor opinion survey. London. http://www.mckinsey.com/features/investor_opinion/index.html

Mehran, H., 1995. Executive compensation structure, ownership, and firm performance. Journal of Financial Economics 38, 168-184.

Miller, D., 1999. The market reaction to international cross-listing: Evidence from depositary receipts. Journal of Financial Economics 51, 103-123.

Mishra, C., Randøy, T., Jenssen, J., 2001. The effect of founding family influence on firm value and corporate governance: A study of Norwegian firms. Journal of International Financial Management and Accounting, forthcoming. 
Modén K., Oxelheim, L., 1997. Why issue equity abroad - corporate efforts and stock market responses. Management International Review 37, 223-241.

Morck, R., Shleifer, A., Vishny, R., 1988. Management ownership and market valuation: An empirical analysis. Journal of Financial Economics 20, 293-315.

Merton, R., 1987. Presidential address: A simple model of capital market equilibrium with incomplete information. Journal of Finance 42, 483-510.

OECD, 1998. Corporate Governance: Improving Competitiveness and Access to Capital in Global Markets. Organization for Economic Cooperation and Development Document, Paris.

OECD, 1999. OECD Principles of Corporate Governance, Organization for Economic Cooperation and Development. http://www.oecd.org/daf/governance/principles.htm

Oslo Stock Exchange, 1999. Foreign Ownership by Country and Investment Sector. http://www.ose.no/relevant_statistics/9902.pdf

Oxelheim, L., Stonehill, A., Randøy, T., Vikkula, K., Dullum, K., Modén, K., 1998. Corporate Strategies to Internationalise the Cost of Capital. Copenhagen Business School Press, Copenhagen.

Oxelheim, L., 2001. Routes to equity market integration - The interplay between politicians, investors and managers. Journal of Multinational Financial Management 11, 183-211.

Peace, C., Osmond, C., 1999. From workplace attitudes and values to a global pattern of nations: An application of latent class modeling. Journal of Management 25, 759-778.

Perfect, S., Wiles, K., 1994. Alternative Constructions of Tobin's Q: An Empirical Comparison. Journal of Empirical Finance 1, 313-341.

Reese, W. Jr., Weisback, M., 2001. Protection of minority shareholder interests, cross-listings in the United States, and subsequent equity offerings. NBER Working Paper \#8164.

Randøy, T., Oxelheim, L. and Stonehill, A., 2001. Global Financial Strategies and Corporate Competitiveness. European Management Journal, 19, Issue 6, forthcoming.

Rosenstein, S., Wyatt, J., 1990. Outside directors, board independence, and shareholder wealth. Journal of Financial Economics 26, 175-192.

Shleifer, A.,Vishny, R., 1986. Large shareholders and corporate control. Journal of Political Economy 94, 461-488.

Shleifer, A., Vishny, R., 1997. A survey of corporate governance. Journal of Finance 52, 737-783.

Spender, J., 1996. Making knowledge the basis of a dynamic theory of the firm. Strategic Mangement Journal 17, 45-62.

Stulz, R., 1999. Globalization, corporate finance and the cost of capital. Journal of Applied Corporate Finance 12 (3): 8-25.

Sundaram, A. K. and D.E. Louge. 1996. Valuation effect of foreign company listings on U.S. exchanges. 
Journal of International Business Studies 27 (1): 67-88.

Sundqvist, S., 1999. Ägarna och Makten i Sveriges Börsföretag, Dagens Nyheters förlag, Stockholm, Sweden.

Useem, M., 1998. Corporate leadership in a globalizing equity market. Academy of Management Executive 12 (4), 43-59.

Yermack, D., 1996. Higher market values of companies with a small board of directors. Journal of Financial Economics 40, 185-211. 
Table 1: Descriptive Statistics of Firms with Anglo-American Board Membership (AABMs) and Boards Without Anglo-American Board Membership (Non-AABMs)

\begin{tabular}{|c|c|c|c|c|c|c|}
\hline \multirow[t]{2}{*}{ Variables } & \multicolumn{3}{|c|}{$\begin{array}{l}\text { Full Sample } \\
(\mathrm{N}=650)\end{array}$} & \multirow{2}{*}{$\begin{array}{c}\begin{array}{c}\text { AABMs } \\
(\mathbf{N}=84)\end{array} \\
\text { Mean }\end{array}$} & \multirow{2}{*}{$\begin{array}{c}\begin{array}{c}\text { Non- } \\
\text { AABMs }\end{array} \\
(\mathrm{N}=568) \\
\text { Mean }\end{array}$} & \multirow{2}{*}{$\begin{array}{c}\text { ANOVA } \\
\text { F-value } \\
\text { between } \\
\text { group } \\
\text { difference }\end{array}$} \\
\hline & Mean & S.D. & $\begin{array}{c}\# \text { of } \\
\text { Observations }\end{array}$ & & & \\
\hline \multicolumn{7}{|l|}{$\begin{array}{l}\text { International Corporate Governance } \\
\text { Variables }\end{array}$} \\
\hline Anglo-American Board Membership & 0.126 & 0.334 & 650 & & & \\
\hline Foreign ownership (\%) & 18.53 & 20.25 & 650 & 38.67 & 15.30 & $114.21^{\star \star *}$ \\
\hline Foreign listing & 0.126 & 0.332 & 650 & 0.441 & 0.076 & $104.04^{* \star *}$ \\
\hline Foreign Subsidiary (\%) & $6.93 \%$ & 25.42 & 650 & 22.62 & 4.44 & $40.92^{\star \star *}$ \\
\hline \multicolumn{7}{|l|}{ General corporate governance } \\
\hline Board size & 7.19 & 2.10 & 650 & 8.26 & 6.98 & $28.06^{\star * *}$ \\
\hline Board independence (\%) & 81.01 & 23.04 & 650 & 76.92 & 81.31 & 2.61 \\
\hline Blockholder ownership (\%) & 43.94 & 20.11 & 650 & 40.39 & 44.58 & $3.24^{\dagger}$ \\
\hline \multicolumn{7}{|l|}{ General control variables } \\
\hline Firm size (In) & 6.96 & 1.87 & 650 & 8.08 & 6.72 & $40.12^{\star \star \star}$ \\
\hline Firm age (In) & 3.64 & 0.99 & 225 & 3.82 & 3.58 & $4.24^{*}$ \\
\hline Debt of total assets (\%) & 57.93 & 20.21 & 650 & 56.44 & 57.93 & 0.135 \\
\hline Asset tangibility (\%) & 53.37 & 25.67 & 650 & 52.14 & 53.14 & 0.12 \\
\hline \multicolumn{7}{|l|}{ Firm Value (log q-value) } \\
\hline All Industries & 0.39 & 0.53 & 650 & 0.61 & 0.36 & $20.91^{\star \star *}$ \\
\hline Retail and Property & 0.21 & 0.28 & 99 & 0.33 & 0.20 & 1.11 \\
\hline Manufacturing Industry & 0.37 & 0.49 & 274 & 0.55 & 0.34 & $6.71^{*}$ \\
\hline Information Technology and Telecom & 0.96 & 0.60 & 86 & 1.44 & 0.89 & $8.89^{* *}$ \\
\hline Media and Publishing & 0.51 & 0.48 & 65 & 0.93 & 0.46 & $6.44^{*}$ \\
\hline Shipping and Transportation Industry & 0.15 & 0.47 & 126 & 0.35 & 0.12 & $3.47^{\dagger}$ \\
\hline
\end{tabular}


Table 2: Pearson Correlation Matrix

\begin{tabular}{|c|c|c|c|c|c|c|c|c|c|c|}
\hline Variables & (1) & (2) & (3) & (4) & (5) & (6) & (7) & (8) & (9) & $(10)$ \\
\hline \multicolumn{11}{|l|}{ 1. Q-value (log) } \\
\hline $\begin{array}{l}\text { 2. Anglo-American } \\
\text { Board Membership }\end{array}$ & .177 & & & & & & & & & \\
\hline $\begin{array}{l}\text { 3. Foreign ownership } \\
(\%)\end{array}$ & .211 & .382 & & & & & & & & \\
\hline 4. Foreign listing & .097 & .367 & .378 & & & & & & & \\
\hline 5. Foreign Subsidiary & .021 & .240 & .340 & .009 & & & & & & \\
\hline 6. Board size & -.095 & .201 & .145 & .331 & .030 & & & & & \\
\hline $\begin{array}{l}\text { 7. Board } \\
\text { independence }\end{array}$ & -.073 & -.058 & .006 & .075 & .038 & .341 & & & & \\
\hline $\begin{array}{l}\text { 8. Blockholder } \\
\text { ownership }\end{array}$ & -.207 & -.074 & -.258 & -.227 & .050 & -.056 & .098 & & & \\
\hline 9. Firm size (log) & -.178 & .254 & .244 & .484 & .110 & .627 & .266 & -.022 & & \\
\hline 10. Firm Age (log) & -.212 & .088 & .005 & .161 & -.010 & .479 & .195 & -.011 & .449 & \\
\hline $\begin{array}{l}\text { 11. Nationality } \\
(\text { Sweden }=1)\end{array}$ & -.087 & .101 & .038 & .063 & -.029 & .425 & .099 & -.069 & .265 & .199 \\
\hline
\end{tabular}

$\mid$ Correlations $\mid>0.101$ significant at $1 \%$ level (two-tailed). $\mid$ Correlations $\mid>0.077$ significant at $5 \%$ level (two-tailed). 
Table 3: OLS Estimates of the Association Between Anglo-American Board Membership, Foreign Ownership, Foreign Listing, and Firm Valuation

\begin{tabular}{|c|c|c|c|}
\hline \multirow[b]{2}{*}{ Sample year: } & \multicolumn{3}{|c|}{$\begin{array}{c}\text { Dependent variable: } \\
\text { Firm value measured as Q-ratio (In) at year- } \\
\text { end. }\end{array}$} \\
\hline & 1996 & 1997 & 1998 \\
\hline $\begin{array}{r}\text { International corporate } \\
\text { governance variables } \\
\text { Anglo-American board } \\
\text { membership }\end{array}$ & $\begin{array}{c}.114 \\
(1.88)^{\dagger}\end{array}$ & $\begin{array}{c}.193 \\
(2.95)^{\star *}\end{array}$ & $\begin{array}{c}.147 \\
(2.19)^{*}\end{array}$ \\
\hline $\begin{array}{r}\text { Foreign ownership (\%) } \\
\text { Foreign listing } \\
\text { Foreign subsidiary }\end{array}$ & $\begin{array}{l}.178 \\
(2.27)^{\star *} \\
.046 \\
(.69) \\
-.078 \\
(-1.37)\end{array}$ & $\begin{array}{l}.110 \\
(1.61) \\
.102 \\
(1.49) \\
-.044 \\
(-.74)\end{array}$ & $\begin{array}{l}.080 \\
(1.04) \\
.107 \\
(1.35) \\
.024 \\
(.33)\end{array}$ \\
\hline $\begin{array}{r}\text { General corporate } \\
\text { governance } \\
\text { Board size }\end{array}$ & $\begin{array}{l}.107 \\
(1.33) \\
.021 \\
(.35) \\
-.086 \\
(-1.43)\end{array}$ & $\begin{array}{c}.027 \\
(.33) \\
-.140 \\
(-2.31)^{\star} \\
-.028 \\
(-.47)\end{array}$ & $\begin{array}{l}-.024 \\
(-.27) \\
-.028 \\
(-.44) \\
-.047 \\
(-.72)\end{array}$ \\
\hline $\begin{array}{r}\text { General control } \\
\text { variables } \\
\text { Firm size (In) } \\
\text { Firm Age } \\
\text { Nationality } \\
\text { (Sweden }=1)\end{array}$ & $\begin{array}{l}-.417 \\
(-4.96)^{\star * *} \\
-.052 \\
(-.81) \\
-.145 \\
(-2.29)^{\star}\end{array}$ & $\begin{array}{l}-.157 \\
(-2.03)^{\star} \\
-.088 \\
(-1.29) \\
-.119 \\
(-1.86)^{\dagger}\end{array}$ & $\begin{array}{l}-.140 \\
(-1.59) \\
-.086 \\
(-1.20) \\
.061 \\
(.86)\end{array}$ \\
\hline $\begin{array}{l}\text { \# of observations } \\
\text { Adjusted R-square }\end{array}$ & $\begin{array}{l}205 \\
0.435\end{array}$ & $\begin{array}{c}222 \\
0.361\end{array}$ & $\begin{array}{c}223 \\
0.257\end{array}$ \\
\hline F-Statistics Significance & $11.47^{\star * *}$ & $9.28^{\star \star \star}$ & $6.09^{* \star}$ \\
\hline $\begin{array}{l}\text { Industry controls are not rep } \\
\text { includes two unreported san } \\
\text { brackets. } \\
{ }^{+} p<.10 \text { (two-tailed) } \\
{ }^{*} p<.05 \text { (two-tailed) } \\
{ }^{* *} p<.01 \text { (two-tailed) } \\
{ }^{* * *} p<.001 \text { (two-tailed) }\end{array}$ & $\begin{array}{l}\text { We use } \\
\text { year dumn }\end{array}$ & $\begin{array}{l}\text { groups } \\
\text { ardized b }\end{array}$ & $\begin{array}{l}\text { le 4. The poole } \\
\text { reported and }\end{array}$ \\
\hline
\end{tabular}


Table 4: Logistic Regression, OLS and 2SLS Estimates of the Association Between AngloAmerican Board Membership and Firm Value (Pooled tests with data from 1996, 1997, and 1998)

\begin{tabular}{|c|c|c|c|}
\hline Methods: & $\begin{array}{l}\text { Logistic } \\
\text { regression }\end{array}$ & OLS & $2 S L S$ \\
\hline Dependent variable: & $\begin{array}{c}\text { Anglo- } \\
\text { American } \\
\text { Board } \\
\text { Membership } \\
\end{array}$ & $\begin{array}{l}\text { Firm value } \\
\text { (In Q-ratio) }\end{array}$ & $\begin{array}{l}\text { Firm value } \\
\text { (In Q-ratio) }\end{array}$ \\
\hline Firm value (In Q-ratio) & $\begin{array}{c}.365 \\
(12.16)^{\star \star \star}\end{array}$ & & \\
\hline $\begin{array}{r}\text { International corporate } \\
\text { governance variables } \\
\text { Anglo-American board } \\
\text { membership }\end{array}$ & & $\begin{array}{c}.148 \\
(4.08)^{\star \star \star}\end{array}$ & $\begin{array}{c}.480 \\
(3.03)^{\star \star}\end{array}$ \\
\hline $\begin{array}{r}\text { Foreign ownership (\%) } \\
\text { Foreign listing } \\
\text { Foreign subsidiary }\end{array}$ & $\begin{array}{c}.029 \\
(13.14)^{\star * \star} \\
1.646 \\
(19.04)^{\star \star \star} \\
1.794 \\
(13.14)^{\star \star *}\end{array}$ & $\begin{array}{l}.128 \\
(3.33)^{\star *} \\
.084 \\
(2.07)^{\star} \\
-.037 \\
(-1.05)\end{array}$ & $\begin{array}{c}-.089 \\
(-2.14)^{*}\end{array}$ \\
\hline $\begin{array}{r}\text { General corporate } \\
\text { governance }\end{array}$ & & & \\
\hline Board size & $\begin{array}{l}.188 \\
(2.92)^{\dagger}\end{array}$ & $\begin{array}{l}.038 \\
(.75)\end{array}$ & $\begin{array}{l}.002 \\
(.04)\end{array}$ \\
\hline Board independence & $\begin{array}{l}-2.050 \\
(6.27)^{*}\end{array}$ & $\begin{array}{l}-.054 \\
(-1.56)\end{array}$ & $\begin{array}{l}-.008 \\
(-.19)\end{array}$ \\
\hline Blockholder ownership & $\begin{array}{l}.017 \\
(4.24)^{*}\end{array}$ & $\begin{array}{c}-.047 \\
(-.1 .34)\end{array}$ & $\begin{array}{c}-.070 \\
(-1.86)^{\dagger}\end{array}$ \\
\hline $\begin{array}{r}\text { General control } \\
\text { variables }\end{array}$ & & & \\
\hline $\begin{array}{r}\text { Firm size }(\text { In) } \\
\text { Firm Age }\end{array}$ & $\begin{array}{l}.151 \\
(1.36) \\
.307 \\
(2.58)\end{array}$ & $\begin{array}{l}-.231 \\
(-4.98)^{\star \star \star} \\
-.069 \\
(-1.79)^{\dagger}\end{array}$ & $\begin{array}{l}-.257 \\
(-5.00)^{\star \star \star} \\
-.069 \\
(-1.66)^{\dagger}\end{array}$ \\
\hline $\begin{array}{r}\text { Nationality } \\
(\text { Sweden }=1)\end{array}$ & $\begin{array}{c}.691 \\
(3.25)^{\dagger}\end{array}$ & $\begin{array}{c}-.071 \\
(-1.76)^{\dagger}\end{array}$ & $\begin{array}{c}-.077 \\
(-1.91)^{\dagger}\end{array}$ \\
\hline $\begin{array}{r}\text { One-digit industry } \\
\text { controls } \\
\text { \# of observations }\end{array}$ & $\begin{array}{l}\text { Yes } \\
650\end{array}$ & $\begin{array}{l}\text { Yes } \\
650\end{array}$ & $\begin{array}{l}\text { Yes } \\
650\end{array}$ \\
\hline $\begin{array}{r}\text { Adjusted R-square } \\
\text { (Cox \& Snell R-square for } \\
\text { logistic regression) }\end{array}$ & 0.234 & 0.371 & 0.304 \\
\hline $\begin{array}{r}\text { F-Statistics Significance } \\
\text { (Wald-statistics for } \\
\text { logistical regression) }\end{array}$ & $319.32^{\star \star \star}$ & $23.48^{\star \star \star}$ & $21.20^{\star * *}$ \\
\hline $\begin{array}{r}\text { Durbin-Watson } \\
\text { (Autocorrelation) }\end{array}$ & & 1.867 & \\
\hline \multicolumn{4}{|c|}{ 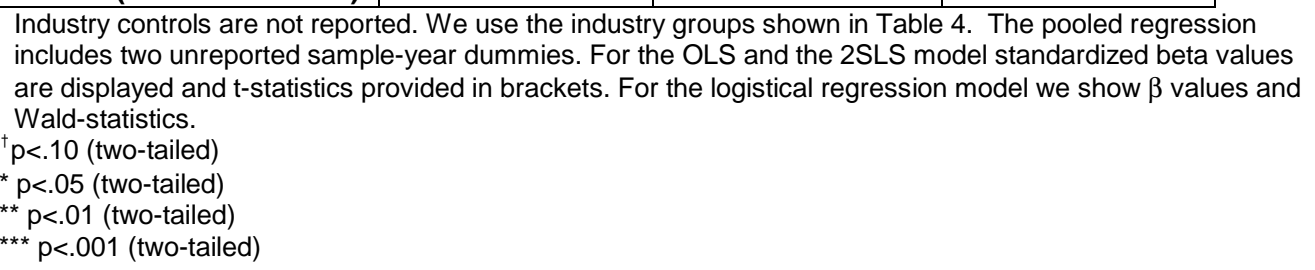 } \\
\hline
\end{tabular}


Table 5: The Effect of Anglo-American Board Membership on Firm Value by Industry (OLS pooled regression 1996, $1997 \& 1998)$

\begin{tabular}{|c|c|c|c|c|c|}
\hline & $\begin{array}{c}\text { Property \& } \\
\text { Retail }\end{array}$ & Manufacturing & IT \& Telecom & $\begin{array}{c}\text { Media \& } \\
\text { Publishing }\end{array}$ & $\begin{array}{l}\text { Transportation } \\
\text { and Shipping }\end{array}$ \\
\hline $\begin{array}{r}\text { International corporate } \\
\text { governance variables } \\
\text { Anglo-American board } \\
\text { membership }\end{array}$ & $\begin{array}{l}.082 \\
(.77)\end{array}$ & $\begin{array}{c}.142 \\
(2.34)^{*}\end{array}$ & $\begin{array}{c}.555 \\
(3.68)^{\star * *}\end{array}$ & $\begin{array}{c}.253 \\
(1.70)^{\dagger}\end{array}$ & $\begin{array}{c}-.002 \\
(-.02)\end{array}$ \\
\hline $\begin{array}{r}\text { Foreign ownership (\%) } \\
\text { Foreign listing } \\
\text { Foreign Subsidiary }\end{array}$ & $\begin{array}{l}-.018 \\
(-.11) \\
-.047 \\
(-.35) \\
-.151 \\
(-1.06)\end{array}$ & $\begin{array}{c}.323 \\
(4.84)^{\star \star \star} \\
.088 \\
(1.12) \\
-.133 \\
(-2.10)^{\star}\end{array}$ & $\begin{array}{l}.132 \\
(1.11) \\
.051 \\
(.36) \\
-.088 \\
(-.58)\end{array}$ & $\begin{array}{l}.220 \\
(1.66) \\
.142 \\
(1.08) \\
-.105 \\
(-.92)\end{array}$ & $\begin{array}{c}-.012 \\
(-.12) \\
.092 \\
(.99) \\
.260 \\
(2.69)^{* *}\end{array}$ \\
\hline $\begin{array}{r}\text { General corporate } \\
\text { governance } \\
\text { Board size }\end{array}$ & $\begin{array}{l}-.044 \\
(-.30) \\
-.178 \\
(-1.54) \\
-.186 \\
(-1.78)^{\dagger}\end{array}$ & $\begin{array}{c}.050 \\
(.59) \\
-.122 \\
(-2.14)^{\star} \\
-.075 \\
(-1.26)\end{array}$ & $\begin{array}{l}-.155 \\
(-.87) \\
.183 \\
(1.42) \\
-.053 \\
(-.45)\end{array}$ & $\begin{array}{c}.038 \\
(.22) \\
.270 \\
(2.43)^{\star} \\
.227 \\
(1.66)\end{array}$ & $\begin{array}{c}-.024 \\
(-.22) \\
-.005 \\
(-.05) \\
-.305 \\
(-3.25)^{\star \star}\end{array}$ \\
\hline $\begin{array}{r}\text { General control } \\
\text { variables } \\
\text { Firm size }(\text { In) } \\
\text { Firm Age } \\
\text { Nationality } \\
(\text { Sweden }=1)\end{array}$ & $\begin{array}{l}.113 \\
(.74) \\
.035 \\
(.29) \\
-.344 \\
(-2.55)^{*}\end{array}$ & $\begin{array}{c}-.371 \\
(-4.63)^{\star * \star} \\
-.141 \\
(-2.36)^{\star} \\
.021 \\
(.35)\end{array}$ & $\begin{array}{c}-.602 \\
(-3.23)^{\star \star} \\
.026 \\
(.17) \\
.178 \\
(1.38)\end{array}$ & $\begin{array}{c}-.023 \\
(-.14) \\
-.249 \\
(-1.71)^{\dagger} \\
-.437 \\
(-3.62)^{\star \star}\end{array}$ & $\begin{array}{l}-.216 \\
(-2.15)^{\star} \\
.049 \\
(.53) \\
-.015 \\
(-.15)\end{array}$ \\
\hline $\begin{array}{r}\text { \# of observations } \\
\text { (firm-years) }\end{array}$ & 99 & 274 & 86 & 65 & 126 \\
\hline $\begin{array}{r}\text { \# of firm-years with one } \\
\text { or more Anglo-American } \\
\text { directors } \\
\text { Adjusted R-square }\end{array}$ & 0.134 & 0.253 & 0.261 & 0.334 & $\begin{array}{c}17 \\
0.236\end{array}$ \\
\hline F-Statistics Significance & $2.26^{*}$ & $8.71^{* * *}$ & $3.44^{* *}$ & $3.67^{\star \star}$ & $4.22^{\star \star \star}$ \\
\hline
\end{tabular}

Standardized beta values are displayed and t-statistics provided in brackets.

${ }^{\dagger} p<10$ (two-tailed)

${ }^{*} \mathrm{p}<.05$ (two-tailed)

${ }^{* *} \mathrm{p}<.01$ (two-tailed)

${ }^{\star \star *} \mathrm{p}<.001$ (two-tailed) 
Table 6: The Effect of Anglo-American Board Membership, on Firm Value under Various Corporate Governance Conditions (OLS pooled regression 1996, 1997 \& 1998)

\begin{tabular}{|c|c|c|c|c|c|c|}
\hline & \multicolumn{2}{|c|}{$\begin{array}{c}\text { Market Capitalization } \\
\text { Subgroups }\end{array}$} & \multicolumn{2}{|c|}{$\begin{array}{l}\text { Firm's Age } \\
\text { Subgroups }\end{array}$} & \multicolumn{2}{|c|}{$\begin{array}{l}\text { Nationality } \\
\text { Subgroups }\end{array}$} \\
\hline & $\begin{array}{l}\text { Less than } \\
\text { SEK } 1 \\
\text { billion } \\
\text { (US\$123 } \\
\text { million) } \\
\end{array}$ & $\begin{array}{l}\text { More than } \\
\text { SEK } 1 \\
\text { billion } \\
\text { (US\$123 } \\
\text { million) }\end{array}$ & $\begin{array}{l}\text { Less than } \\
30 \text { years } \\
\text { old }\end{array}$ & $\begin{array}{l}30 \text { years or } \\
\text { older }\end{array}$ & Norwegian & Swedish \\
\hline $\begin{array}{r}\text { International corporate } \\
\text { governance variables } \\
\text { Anglo-American Board } \\
\text { Membership }\end{array}$ & $\begin{array}{c}.099 \\
(2.16)^{*}\end{array}$ & $\begin{array}{c}.174 \\
(3.76)^{\star \star \star}\end{array}$ & $\begin{array}{c}.114 \\
(2.07)^{*}\end{array}$ & $\begin{array}{c}.140 \\
(2.66)^{\star *}\end{array}$ & $\begin{array}{c}.104 \\
(2.15)^{\star}\end{array}$ & $\begin{array}{c}.245 \\
(4.43)^{\star \star *}\end{array}$ \\
\hline Foreign ownership (\%) & $\begin{array}{l}.034 \\
(.73)\end{array}$ & $\begin{array}{l}.218 \\
(3.76)^{\star * \star}\end{array}$ & $\begin{array}{l}.043 \\
(.80)\end{array}$ & $\begin{array}{l}.210 \\
(3.68)^{\star * \star}\end{array}$ & $\begin{array}{l}.121 \\
(2.46)^{*}\end{array}$ & $\begin{array}{c}.158 \\
(2.43)^{*}\end{array}$ \\
\hline Foreign listing & $\begin{array}{l}.030 \\
(.69)\end{array}$ & $\begin{array}{l}.023 \\
(.71)\end{array}$ & $\begin{array}{l}.136 \\
(2.54)^{*}\end{array}$ & $\begin{array}{l}-.010 \\
(-.16)\end{array}$ & $\begin{array}{l}.075 \\
(1.49)\end{array}$ & $\begin{array}{l}.081 \\
(1.11)\end{array}$ \\
\hline Foreign Subsidiary & $\begin{array}{l}-.034 \\
(-.76)\end{array}$ & $\begin{array}{l}-.146 \\
(-2.56)^{*}\end{array}$ & $\begin{array}{l}.096 \\
(1.71)^{\dagger}\end{array}$ & $\begin{array}{l}-.127 \\
(-2.53)^{*}\end{array}$ & $\begin{array}{l}.006 \\
(.14)\end{array}$ & $\begin{array}{c}-.102 \\
(-1.72)^{\dagger}\end{array}$ \\
\hline $\begin{array}{r}\text { General corporate } \\
\text { governance }\end{array}$ & & & & & & \\
\hline $\begin{array}{l}\text { Board size } \\
\text { Board independence } \\
\text { Blockholder ownership }\end{array}$ & $\begin{array}{l}.021 \\
(.40) \\
.021 \\
(.48) \\
-.032 \\
(-.69)\end{array}$ & $\begin{array}{c}.005 \\
(.07) \\
-.228 \\
(-3.92)^{\star * \star *} \\
-.016 \\
(-.30)\end{array}$ & $\begin{array}{l}.039 \\
(.61) \\
-.038 \\
(-.74) \\
.049 \\
(-.86)\end{array}$ & $\begin{array}{l}-.007 \\
(-.10) \\
-.031 \\
(-.59) \\
-.065 \\
(-1.31)\end{array}$ & $\begin{array}{c}-.007 \\
(-.14 \\
-.024 \\
(-.48 \\
-.102 \\
(-2.19)^{*}\end{array}$ & $\begin{array}{c}.066 \\
(.93) \\
-.127 \\
(-2.56)^{\star} \\
.030 \\
(.54)\end{array}$ \\
\hline General control variables & & & & & & \\
\hline $\begin{array}{r}\text { Firm size }(\mathrm{In}) \\
\text { Firm Age } \\
\text { Nationality } \\
(\text { Sweden }=1)\end{array}$ & $\begin{array}{c}-.261 \\
(-5.30)^{\star \star \star} \\
-.114 \\
(-2.25)^{\star} \\
-.095 \\
(-2.01)^{\star}\end{array}$ & $\begin{array}{l}-.307 \\
(-4.38)^{\star \star \star} \\
-.076 \\
(-1.38) \\
-.022 \\
(-.39)\end{array}$ & $\begin{array}{c}-.386 \\
(-5.44)^{\star \star \star} \\
.090 \\
(1.66)^{\dagger} \\
0.065 \\
(.74)\end{array}$ & $\begin{array}{c}-.084 \\
(-1.27) \\
-.103 \\
(-2.03)^{\star} \\
-.086 \\
(-1.55)\end{array}$ & $\begin{array}{l}-.245 \\
(-4.35)^{\star \star \star} \\
-.065 \\
(-1.24)\end{array}$ & $\begin{array}{c}-.181 \\
(-2.36)^{*} \\
-.154 \\
(-2.69)^{* *}\end{array}$ \\
\hline $\begin{array}{r}\text { Number of observations } \\
\text { (firms) }\end{array}$ & 375 & 275 & 270 & 380 & 354 & 296 \\
\hline Adjusted R-square & 0.417 & 0.430 & 0.462 & 0.233 & 0.394 & 0.364 \\
\hline F-Statistics Significance & $16.55^{\star \star \star}$ & $13.27^{\star \star \star}$ & $14.38^{* * *}$ & $7.82^{\star \star \star}$ & $15.32^{\star \star \star}$ & $11.43^{\star \star \star}$ \\
\hline
\end{tabular}

Industry controls are not reported. We use the industry groups shown in Table 4. Standardized beta values are displayed and tstatistics provided in brackets.

${ }^{\dagger} \mathrm{p}<.10$ (two-tailed)

${ }^{*} p<.05$ (two-tailed)

** $p<.01$ (two-tailed)

${ }^{\star \star \star} \mathrm{p}<.001$ (two-tailed) 
Table 7: CEO Tenure and Firm Performance Among Firms With and Without Anglo-American Board Membership

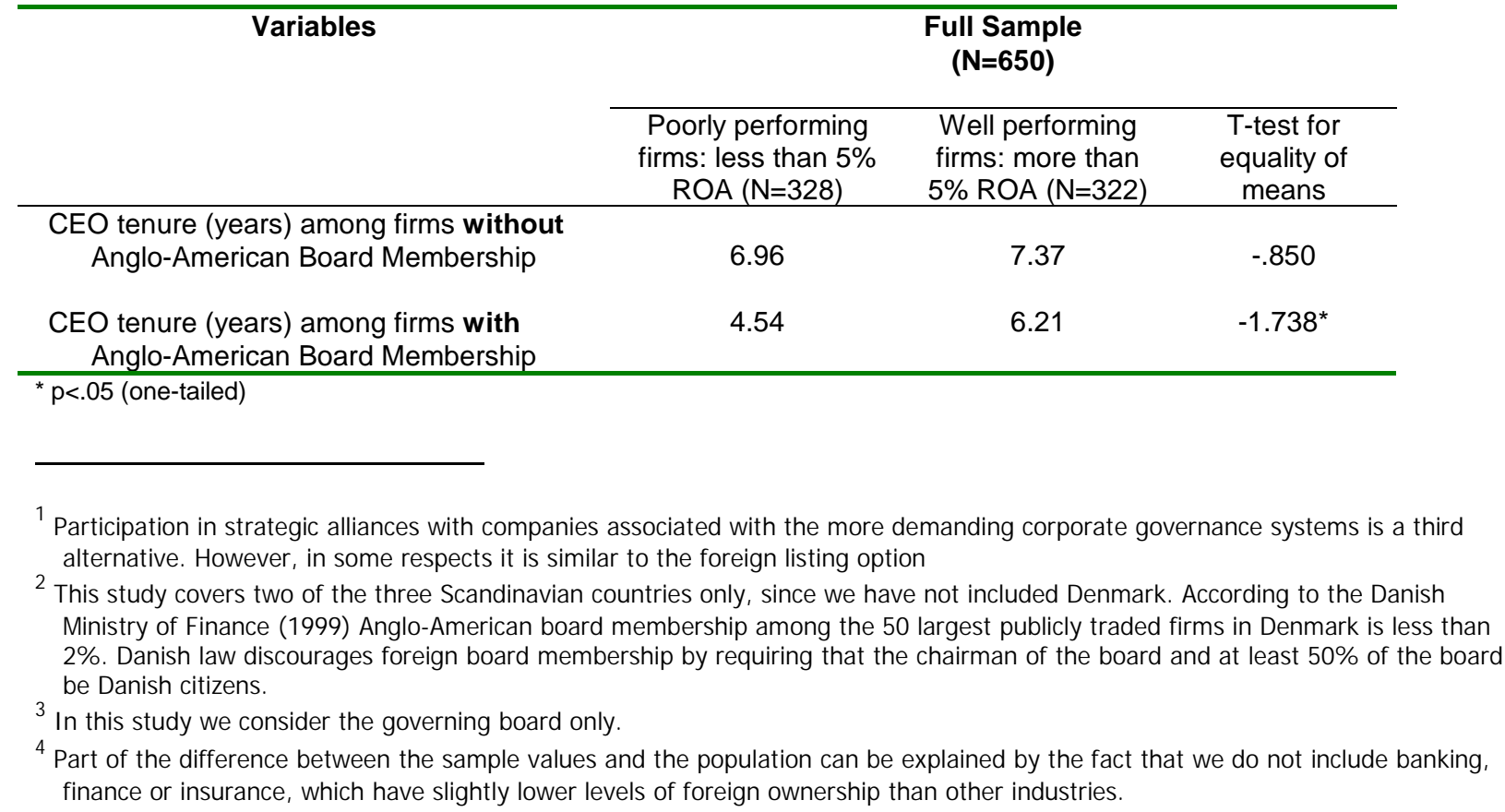

